\title{
The Mode of Regulation of Bacterial Citrate Synthase as a Taxonomic Tool
}

\author{
By P. D. J. WEITZMAN AND DOROTHY JONES \\ Department of Biochemistry and M.R.C. Microbial Systematics Unit, \\ School of Biological Sciences, The University, Leicester LEI $7 R H$
}

(Received 28 November 1974; revised 26 February 1975)

\section{INTRODUCTION}

Certain properties of bacterial citrate synthases may be taxonomically useful. Citrate synthases from Gram-negative bacteria are inhibited by NADH. This inhibition can be overcome by AMP only in strictly aerobic Gram-negative bacteria (Weitzman \& Jones, I968; Jones \& Weitzman, I971, 1974). Further, the citrate synthases of Gram-negative bacteria have been classified as 'large' (mol. wt approx. 250000) whereas those from Grampositive bacteria are 'small' (mol. wt approx. I00000) (Weitzman \& Dunmore, 1969).

We here report the properties of citrate synthase from several bacteria which either give an equivocal Gram reaction or whose taxonomic position is uncertain for other reasons.

\section{METHODS}

Strains. The bacteria used are listed in Table $\mathbf{I}$.

Gram stain. Gram stains were performed as described by Baker (1967). Acetone was used as the decolourizer and carbol fuchsin as the counter stain.

Preparation of extracts. All bacteria were grown in $500 \mathrm{ml}$ nutrient broth (Oxoid) in 21 flasks, with shaking, for $24 \mathrm{~h}$ at $30^{\circ} \mathrm{C}$. Bacteria were collected by centrifuging at $25000 \mathrm{~g}$ for Io min, washed with buffer of composition $20 \mathrm{mM}$-tris (hydroxymethyl) aminomethanehydrochloride ( $\mathrm{pH} \mathrm{8.0)}$, $10 \mathrm{mM}-\mathrm{MgCl}_{2}$ and I mM-ethylenediaminetetracetic acid, and disrupted by ultrasonic treatment in an MSE $100 \mathrm{~W}$ sonicator for $2 \mathrm{~min}$ at full power with cooling. After centrifuging again at $25000 \mathrm{~g}$ for $\mathrm{IO} \mathrm{min}$ the supernatants were used without further purification.

Enzyme studies. Measurement of citrate synthase activity and of the effects of NADH and AMP were carried out spectrophotometrically at 4I $2 \mathrm{~nm}$ as previously described (Weitzman \& Jones, 1968).

The molecular size of citrate synthase was determined by gel filtration on Sephadex G200 using catalase (beef liver, 2 times crystallized; Sigma) and lactate dehydrogenase (rabbit muscle, The Boehringer Corp., Ltd, London) as marker proteins (Weitzman \& Dunmore, 1969). 'Large' citrate synthases were eluted before catalase and 'small' enzymes were eluted after lactate dehydrogenase.

\section{RESULTS AND DISCUSSION}

The characteristics of the citrate synthases from 9 strains of bacteria are listed in Table $\mathrm{I}$.

Cellulomonas rossica NCIB8074 and Corynebacterium nephridii ATCCII 425 were found to have citrate synthases characteristic of Gram-negative bacteria. Clark (I95I, I952) con- 
Table I. Characteristics of citrate synthases from different bacteria

No citrate synthase was demonstrated in Gemella haemolysans NCrcio244.

\begin{tabular}{|c|c|c|c|c|}
\hline & $\begin{array}{l}\text { Inhibition } \\
\text { by NADH }\end{array}$ & $\begin{array}{l}\text { Reactivation } \\
\text { by AMP }\end{array}$ & $\begin{array}{l}\text { Molecular } \\
\text { size }\end{array}$ & $\begin{array}{l}\text { Gram reaction } \\
\text { of bacteria }\end{array}$ \\
\hline $\begin{array}{l}\text { Achromobacter liquefaciens } \\
\text { ATCCI5716 }\end{array}$ & - & - & Small & \pm \\
\hline Aeromonas formicans & + & - & Large & - \\
\hline $\begin{array}{l}\text { ATCCI } 3137 \\
\text { Cellulomonas rossica } \\
\text { NCIB } 8074\end{array}$ & + & + & Large & $\mp$ \\
\hline $\begin{array}{l}\text { Corynebacterium nephridii } \\
\text { ATCCI } 1425\end{array}$ & + & + & Large & $\mp$ \\
\hline $\begin{array}{l}\text { Haemophilus vaginalis } \\
\text { NCTCIO287 }\end{array}$ & - & - & Small & $\mp$ \\
\hline $\begin{array}{l}\text { Pseudomonas iodinum } \\
\text { NCIB8179 }\end{array}$ & - & - & Small & \pm \\
\hline $\begin{array}{l}\text { Pseudomonas aeruginosa* } \\
\text { NCIB8295 }\end{array}$ & + & + & Large & - \\
\hline Escherichia coli* ${ }^{*}$ & + & - & Large & - \\
\hline $\begin{array}{l}\text { Brevibacterium linens* } \\
\text { ATCC9174 }\end{array}$ & - & - & Small & + \\
\hline
\end{tabular}

sidered Cel. rossica to be Gram-negative and suggested its removal from the genus Cellulomonas. Our results support this view. Corynebacterium nephridii, described as a Grampositive bacterium by Büsing, Döll \& Freytag (1953), was thought to be Gram-negative by Hart, Larson \& McClesky (I965) and this opinion is supported by our results.

Achromobacter liquefaciens ATCC15716, Haemophilus vaginalis NCTC10287 and Pseudomonas iodinum NCIB8I 79 possessed citrate synthases characteristic of Gram-positive bacteria. These results are in agreement with the views of many other workers. Thornley (1967) and Jones (I975) reported that the Gram staining reaction of Ach. liquefaciens was more nearly Gram-positive than Gram-negative and a numerical taxonomic study by Jones (I975) indicated a close relationship between this bacterium and certain Gram-positive bacteria.

Haemophilus vaginalis usually gives a Gram-negative staining reaction and Criswell et al. (1972) interpreted electron micrographs of thin sections of the wall as indicating a structure typical of Gram-negative bacteria. However, other workers are of the opinion that it is Gram-positive (Zinneman \& Turner, 1963; Reyn, Birch-Andersen \& Lapage, 1966; Dunkelberg, Skaggs \& Kellogg, I970; Vice \& Smaron, 1973). Our results support the latter view.

Pseudomonas iodinum NCIB8I 79 is a species incertae sedis in the latest edition of Bergey's Manual of Determinative Bacteriology (1974). Described by Davis (1939) as invariably Gram-negative and named Chromobacterium iodinum, it was later transferred to the genus Pseudomonas (Tobie, I945). Sneath (1956) described it as undoubtedly Gram-positive and this was later confirmed by Colwell et al. (I969) who concluded it was probably better classified in the Gram-positive genus Arthrobacter.

There has been controversy over the taxonomic position of Aeromonas formicans ATCCI 3 I 37 since it was described by Crawford (I954) because, although its metabolism resembles that of Escherichia coli, it is a polarly-flagellated rod. Colwell \& Liston (I96I) thought it was closely related to Pseudomonas spp, but later biochemical studies showed it to contain 
a $\beta$-galactosidase similar to that of $E$. coli (Rohlfing \& Crawford, I966) and that the mode of tryptophan synthesis in Aer. formicans was similar to that in the enterobacteria (Crawford, Sikes \& Melhorn, 1967). Our results are in agreement with the latter findings.

Gemella haemolysans NCTCI0244, first described as a Gram-negative coccus Neisseria haemolysans (Thjøtta \& Bøe, 1938), is now considered to be a Gram-positive coccus in the genus Gemella in the family Streptococcaceae (Reyn et al. 1966; Reyn, 1970; Reyn, BirchAndersen \& Berger, 1970). The lack of demonstrable citrate synthase in this bacterium supports this classification (Weitzman \& Jones, 1968).

The reaction of bacteria to treatment with the Gram stain has long been considered a character of fundamental importance in bacterial classification. This difference has been reinforced by electron microscopy studies of cell wall structure (Glauert \& Thornley, I969) and the lack of genetic exchange between the two groups (Jones \& Sneath, 1970).

In most cases the Gram reaction of bacteria is unequivocal but there are some bacteria whose reactions to the Gram stain are not clear-cut. This difficulty can generally be clarified by examination of thin sections of the cell wall by electron microscopy. However, this procedure does not always resolve the problem as, for example, in the case of $H$. vaginalis discussed above. Furthermore, the technique is not always available to bacteriologists and is a laborious procedure best performed and interpreted by specialists. In such cases the different regulatory and molecular properties of citrate synthase may provide the extra evidence required.

In other cases examination of citrate synthase may offer a first clue to misclassification. Such an example is provided by our study of the enzyme from Brevibacterium leucinophagum ATCCI3809 (Jones \& Weitzman, 1974). The citrate synthase of this supposedly Grampositive bacterium was found to be of the Gram-negative type, suggesting an error in classification, and a thorough examination, including electron microscopy studies, confirmed that this bacterium is indeed Gram-negative. These results emphasize the value of studies on citrate synthase in establishing taxonomic relationships amongst bacteria.

We thank Mrs Janet K. Hewson for skilled technical assistance. One of us (P.D.J.W.) acknowledges support from the Science Research Council (Grants B/SR 8065.8 and B/RG 4595.2).

\section{REFERENCES}

BAKER, F. J. (1967). Handbook of Bacteriological Technique, 2nd edn. London: Butterworths.

Bergey's Manual of Determinative BaCteriology (1974), 8th edn. Edited by R. E. Buchanan and N. E. Gibbons. Baltimore: The Williams \& Wilkins Co.

Büsing, K.-H., Döll, W. \& Freytag, K. (1953). Die Bakterienflora der medizinischen Blutegel. Archiv für Mikrobiologie 19, 52-86.

Clark, F. E. (195I). The generic classification of certain cellulolytic bacteria. Soil Science Society American Proceedings 15, 180-1 82.

Clark, F. E. (1952). The generic classification of the soil corynebacteria. International Bulletin of Bacteriological Nomenclature and Taxonomy 2, 45-56.

Colwell, R. R., Citarella, R. V., Ryman, I. \& Chapman, G. B. (1969). Properties of Pseudomonas iodinum. Canadian Journal of Microbiology $\mathbf{r}_{5}, 85 \mathrm{I}-857$.

Colwell, 'R. R. \& Liston, J. (I96I). Taxonomic relationships among the pseudomonads. Journal of Bacteriology 82, I-I4.

Crawford, I. P. (I954). A new fermentative pseudomonad, Pseudomonas formicans n.sp. Journal of Bacteriology 68, 734-738.

Crawford, I. P., Sikes, S. \& Melhorn, D. K. (1967). The natural relationships of Aeromonas formicans. Archiv für Mikrobiologie 59, 72-81.

Criswell, B. S., Stenback, W. A., Black, S. H. \& Gardner, H. L. (I972). Fine structure of Haemophilus vaginalis. Journal of Bacteriology 109, 930-932. 
DAvis, J. G. (1939). Chromobacterium iodinum (n.sp). Zentralblatt für Bakteriologie, Parasitenkunde, Infektionskrankheiten und Hygiene (Abteilung II) roo, 273-276.

Dunkelberg, W. E., Skaggs, R. \& Kellogg, D. S. (1970). A study and new description of Corynebacterium vaginale (Haemophilus vaginalis). American Journal of Clinical Pathology 53, 370-377.

Glauert, A. M. \& Thornley, M. J. (I969). The topography of the bacterial cell wall. Annual Review of Microbiology 23, 159-198.

Hart, L. T., Larson, A. D. \& MCClesky, C. S. (1965). Denitrification by Corynebacterium nephridii. Journal of Bacteriology 89, I $104-1108$.

JONES, D. (1975). A numerical taxonomic study of coryneform and related bacteria. Journal of General Microbiology 87, 52-96.

Jones, D. \& SNEATH, P. H. A. (I970). Genetic transfer and bacterial taxonomy. Bacteriological Reviews 34, 40-8I.

Jones, D. \& WeItzman, P. D. J. (197I). Taxonomic significance of citrate synthase. Journal of General Microbiology 69, xi.

Jones, D. \& WeItzman, P. D. J. (1974). Reclassification of Brevibacterium leucinophagum Kinney and Werkman as a Gram negative organism, probably in the genus Acinetobacter. International Journal of Systematic Bacteriology 24, I I 3-I I 7.

Reyn, A. (1970). Taxonomic position of Neisseria haemolysans (Thjøtta \& Bøe 1938). International Journal of Systematic Bacteriology 20, 19-22.

Reyn, A., Birch-Andersen, A. \& Berger, V. (1970). Fine structure and taxonomic position of Neisseria haemolysans (Thjøtta and Bøe 1938) or Gemella haemolysans (Berger, 1960). Acta pathologica et microbiologica scandinavica $B$ 78, 375-389.

Reyn, A., Birch-Andersen, A. \& Lapage, S. P. (I966). An electron microscope study of thin sections of Haemophilus vaginalis (Gardner \& Dukes) and some possibly related bacteria. Canadian Journal of Microbiology 12, I I 25-I I 36.

Rohlfing, S. R. \& CRAWford, I. P. (1966). Purification and characterization of the $\beta$-galactosidase of Aeromonas formicans. Journal of Bacteriology 91, 1085-1097.

SNEATH, P. H. A. (1956). Cultural and biochemical characteristics of the genus Chromobacterium. Journal of General Microbiology 15, 70-98.

Тнјøтта, T. \& Bøе, J. (1938). A haemolytic species of Neisseria Trevisan. Acta pathologica et microbiologica scandinavica $B, \mathrm{S37}, 527-531$.

Thornley, M. J. (1967). A taxonomic study of Acinetobacter and related genera. Journal of General Microbiology 49, 2 I I-257.

ToвiE, W. C. (1945). A proposed biochemical basis for the genus Pseudomonas. Journal of Bacteriology 49, 459-462.

Vice, J. L. \& Smaron, M. F. (1973). Indirect fluorescent-antibody method for the identification of Corynebacterium vaginale. Applied Microbiology 25, 908-916.

Weitzman, P. D. J. \& Dunmore, P. (1969). Citrate synthase: allosteric regulation and molecular size. Biochimica et biophysica acta $\mathbf{1 7}$, $198-200$.

Weitzman, P. D. J. \& Jones, D. (1968). Regulation of citrate synthase and microbial taxonomy. Nature, London 219, 270-272.

Zinneman, K. \& Turner, G. C. (1963). The taxonomic position of 'Haemophilus vaginalis' (Corynebacterium vaginale). Journal of Pathology and Bacteriology 85, 21 3-2 I9. 